\title{
EVALUATION OF LUNG AUSCULTATION IN ACUTE VIRAL BRONCHIOLITIS
}

\author{
Derrick Fassbind ${ }^{1}$, Dâmaris Dorsdt ${ }^{2}$, Brenda Biegelmeyer ${ }^{2}$, Camila de Souza ${ }^{2}$, Debora \\ Decol$^{2}$, Magda Lunelli ${ }^{1}$, Luis Ribeiro ${ }^{1}$, Flávia Rodrigues ${ }^{1}$, Mohamed-Rida Benissa ${ }^{3}$, and \\ Sérgio Amantéa ${ }^{2}$ \\ ${ }^{1}$ Santo Antônio Children Hospital \\ ${ }^{2}$ Federal University of Health Sciences of Porto Alegre Faculty of Medicine \\ ${ }^{3}$ University Hospitals of Geneva Child and Adolescent Department
}

May 27, 2020

\begin{abstract}
Introduction: The diagnosis of acute viral bronchiolitis (AVB) is primarily based on the findings in pulmonary auscultation. There is no consensus on which auscultatory finding is the most frequent in AVB. This study aims to describe the pulmonary auscultation in a series of patients with AVB and verify its association with age, sex, viral agent, and duration of oxygen therapy. Method: Pulmonary auscultation was recorded in patients hospitalized for AVB between October 2018 and October 2019 using an electronic stethoscope and then parallelly analyzed by two examiners. The effect of other factors such as sex, age, duration of oxygen therapy and etiological agent was analyzed for any possible associations. Results: Of 114 patients, 67 (58.8\%) produced wheeze, $43(37.7 \%)$ produced crackles, and $4(3.5 \%)$ had normal auscultation. Wheezing was predominant in male patients while crackling in female patients $(67.1 \%$ and $52.3 \%$, respectively; $\mathrm{p}=0.039)$. Age had no significant influence on the auscultation pattern $(\mathrm{p}=0.054)$, etiological agent $(\mathrm{p}=0.053)$ and the duration of oxygen therapy $(\mathrm{p}=0.877)$. The median age was higher in patients with parainfluenza compared to those with RSV (6.5 and 4.4 months, respectively; p = 0.044). The duration of oxygen therapy was higher in patients with RSV compared to those with no identified virus (median 5.2 and 2.68 days, respectively; $\mathrm{p}=0.018$ ). Conclusions: Wheezing was recorded as the predominant auscultation finding among hospitalized patients with AVB. The type of virus associated with AVB had no influence on the changes in pulmonary auscultation.
\end{abstract}

\section{Hosted file}

MAIN DOCUMENT.doc available at https://authorea.com/users/326813/articles/454576-evaluationof-lung-auscultation-in-acute-viral-bronchiolitis

\section{Hosted file}

TABLES.docx available at https://authorea.com/users/326813/articles/454576-evaluation-oflung-auscultation-in-acute-viral-bronchiolitis 